\title{
WOMEN RIGHTS IN SOUTH ASIA: CASE OF PAKISTAN
}

Yasmin Syed, Lecturer, Department of Sociology, SBKW University, Quetta - Pakistan (yasmin.syed09@gmail.com)

Safia Habib, Lecturer, Department of Sociology, SBKW University, Quetta - Pakistan (safiashah123@gmail.com)

Farah Naseer, Lecturer, Department of Sociology, SBKW University, Quetta - Pakistan (farahnaseersoc@gmail.com)

\begin{abstract}
This research study is lead to explore the challenges faced by working women in balancing work and family life at universities of Quetta city of Pakistan. Usually Men are assuming to perform strength require activities which are not purely distributed to male in underdeveloped countries. In reality female are more engaged in these activities rather than male. Women play the list of roles as a mother, sister, wife, daughter, as a working women in our lives that are beyond compare. Pakistan is male dominated society it is a fact that the status of women has changed than past but still she faced problems and challenges especially as working women. Working women with high work load and lack of leaves are unable to attend their family functions as well as unable to give proper attention to their family members. The research study was quantitative in nature. The researcher select 115 university teachers for study their work life balance through simple random sampling The data was collected through questionnaire technique. The collected data were coded and edited and were analyzed through using SPSS. Chi-square test was applied to analyze the factors like time and household management. Teaching is one of the elegant professions. Lecturers or professors with work stress and depression cannot produce best students .specially it become a challenge for married women to maintain balance between work and family life. Therefore the need was felt to investigate the factors like time management that create hurdles in balancing both private and work life. This study is equally important for academics, researchers and organizations. The findings indicates that those women with initial years of their marital life find more difficulties in managing between their dual lives because at that stage they have the responsibility of small kids with domestic core management as well as they required extra potential and abilities to cope with office demands which creates role conflict for them. The study found that little relaxation in office timing, availability of day care centers and opportunity of job sharing makes the life of working women more relaxed.
\end{abstract}

KEYWORDS work life balance, married working women, time management. 


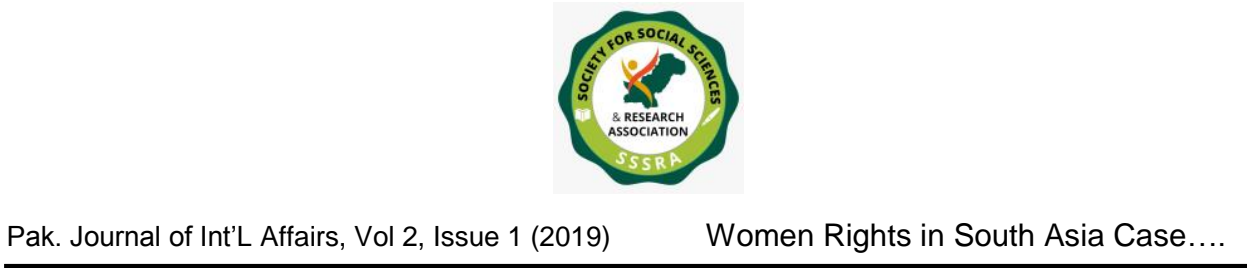

\title{
INTRODUCTION
}

\author{
"I am a woman, I am admired because I do things \\ well; I cook, sew, knit, talk, work and make love very \\ well; so I'm a valuable living being". -
}

Billson

\section{Christ}

Women play the list of roles as a mother, sister, wife, daughter, as a working women in our lives that are beyond compare. We cannot describe the power of a woman in words, which shows the excellent qualities of sympathy, understanding, to be in love. Almost half of our population consists of women. Today, women around the world and make a mark in every field and demonstrate that they are the best. They are remarkable people contributed to raising the economy of our country and are the backbone of any nation. Usually Men are assuming to perform strength require activities which are not purely distributed to male in underdeveloped countries. In reality female are more engaged in these activities rather than male. (Begum, 2002) (Desai, 1967) Drawing attention towards the changing status of women and said, "Now woman is no longer the reproductive machinery of children and looked after at home. She acquires and achieved a new position in society." (Seth, 1995) It is an undeniable fact that now the position of women is rise up as compared past. But still a woman cannot become independent. She faced many troubles and challenges, especially as a working woman. The conditions of married working women are more severe because she has to play a double role; that is as a working woman as well as a house wife.

\section{PROBLEM OF MANAGING TIME}

Typically, women have to look after their kitchen and home side by side with their work responsibilities. In order to complete each and everything, they must not only budget their time. But they must also be bendable, which is anticipated to be available around the clock is. Thus they find their selves in an impossible in difficult situation. Due to this they are unable to satisfy their family and work life tasks; thus the balance between 


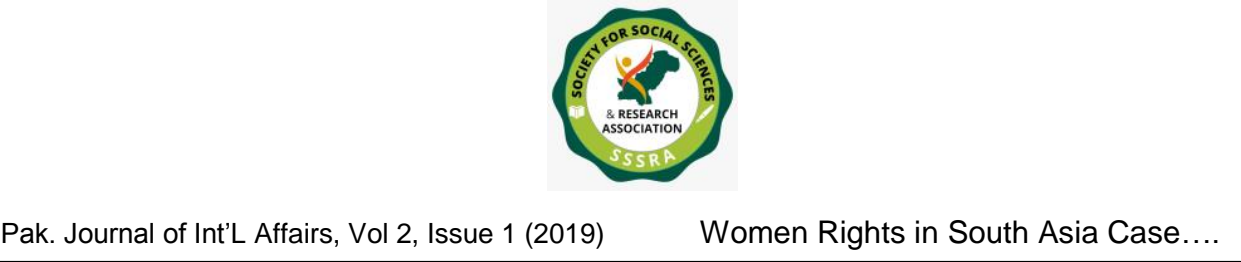

work and life involves finding a happy way in which one can meet the tasks of work and home. In fact, people often spend time facing a dilemma, "which they did not have enough time to meet the demands of both work and home (Hochschild, 1997) It includes a balance between work and life balance is seen between work and the rest of life - the ability to fulfill their obligations at home or at work (Guest, (2002)

\section{CHALLENGES FACED BY WORKING WOMEN IN INDIA}

Like Pakistan working women in India also faced a lot of challenges in balancing these two domain work and family then other parts of the world. India as a male dominated society do not permits man to take responsibility on the vast majority of the family chores, it is ladies who must cook, clean the house, do those dishes, wash clothes, get their kids prepared to school. Men just took care of few chores that are to be dealt outside the house. So the major load of organization the family chores is on the shoulders of females. It was alright for women to handle all the chores as long as they were homemakers. At this time with increasing demand of economic needs puts the women in work force for getting some income for their family, they have to work harder. They have to take up a 9 to 5 job with all the household chores managements that they hold as a homemaker. The role of man has not changed much. (Neetu, (2009))

In India most of the families are still leaving in joint family system with their parents and other in-laws. This situation also creates stress for working women because they have to look after all their husband's family members and try to please them. They are living with the hope that the time for them will change. Mostly we have given up that hope that something can be changed so they have to compromise that situation. (Neetu, (2009))

\section{STATEMENT OF PROBLEM}

In Pakistan women suffer at the time of their birth from most of their basic and fundamental rights. The condition of women is very miserable like many under develop countries. 


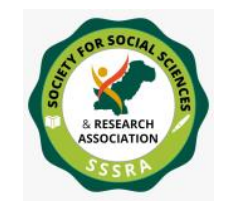

Pak. Journal of Int'L Affairs, Vol 2, Issue 1 (2019)

Women Rights in South Asia Case....

The most critical situation faced by working women when the they become a mother they have to look after their small children at home as well as in office timing they have to leave their children in the hands of then whom they have little trust or in day care. Due to this depressive situation they cannot concentrate on their work. Although most women hired maids and servant for domestic affairs for that they have to pay them more and have to work more hard. Working women with high work load and lack of leaves are unable to attend their family functions as well as unable to give proper attention to their family members which creates guilt for them.

\section{PURPOSE OF STUDY:}

The researcher select university teachers for study their work life balance. It's a well-known fact that successes of nation depend on its students their quality of education. Teaching is one of the elegant professions. Lecturers or professors with work stress and depression cannot produce best students .specially it become a challenge for married women to maintain balance between work and family life. Therefore the need was felt to investigate the factors that create hurdles in balancing both private and work life. The main aim of this research is to explore how women's roles at work and home interact with each other and focuses specifically on role conflicts which may arise in their lives as a challenge.

\section{SCOPE OF STUDY:}

This is an important study for academics, researchers and organizations internationally this study is an attempt to provide insight knowledge about the relationship between work life balances, job stress and job satisfaction among university lecturers. The aim of this study is to advantage all that women both nationally and internationally level who are taking their profession together with their household management.

\section{LITERATURE REVIEW}




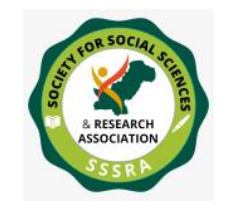

Review of relevant literature is an important step in conducting research. It helps to clarify and define the problem and identify the objectives, formulate hypotheses, appropriate design and choose the method of study and interpret the results in light of the research already carried out. (Sinha, 1976) Conduct a comparative study among female school and college teachers with non-working house wives in which she analyze the experience of role conflict in performing their single and double roles. The sample of the study consists of 280 respondents from Patna city. In which 140 were teachers and140 were house wives with having children. The study found that working women experience high degree of role conflict as compared to non-working house wives. Study investigate that working women face great role conflict in their fulfillment of their role expectations in conflicting situation she neither took care of family member nor properly fulfill the job requirements. They face intraindividual conflict like their spouses have unfavorable attitude towards their job, they have the difficulty of time management as well. (Pietromonaco, Paula.R., 1986)

In their study explored all positive and negative results of multiple roles of working life. The data was collect from 500 working women and examined the responses about the job satisfaction and life satisfaction. The study found that the lives of people with stress and depression did not depend on holding multiple roles. The study suggested that there were great personal and psychological satisfaction prevail among married working women with their multiple roles. (Singh, 1972)Attempt a study "career and family women's two roles (a study on role conflict) found that $25 \%$ of respondents satisfactory giving time to their family and children. Majority of the respondents were not satisfied with time and attention given to their families and children because they have high work load at their work places. The study found that dissatisfaction prevailed among women because they share economic necessities of their family with domestic responsibilities. (Nye, F.I.Hoffman,L.W, 1963) conduct a study on role conflict with work and home found the rearing and caring of children, their homework for school and their other activities like accidents, level of satisfaction of husbands with their wives household management were closely related to time conflict. (De Souza, 1963) The 


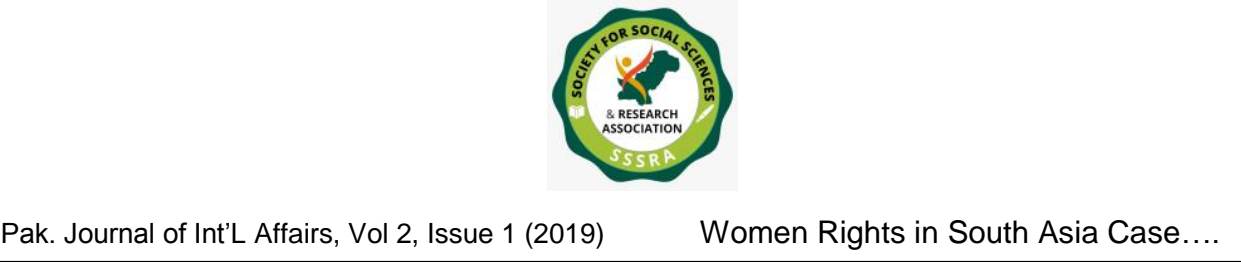

problem for working mothers carrying dual responsibilities at home and work, and suggests that it should fulfill the growing demand for services that allow them to double responsibility. Family life in general and children in particular are creating problems for working mothers separate factors. Among the factors that cause conflict of roles, age and number of children is very important because of the personal attention is important for children when they are growing up. Less time, more congruent with the requirements and roles, working mother feels more and more role conflict situations in Modern. (Mani, 2013)The role conflicts, such as care, lack of recognition, organizational politics, gender discrimination, the elderly and children on the Work Life Balance women in India has revealed the influence of the main factors in time management and lack of proper social assistance, health standards, are problem. (Hom, P.W., and Kinicki, A.J.,, 2001) Checked that the organization consider and use policies that manage the balance between work and life of their employees. Therefore organizations provide increased principle to adopt policies that can reduce employee loss (Mark Tausig and RudyFenwic, 2001)

Worried that working hours alternate affect perceived imbalance between professional lives of "bonding time." However, the perceived control of working hours increases between work life balance net of familiar features and work. The imbalance prediction feature family more consistent is to be a father. The imbalance of labor forecasting feature is more consistent hours worked. Since track hours worked, women and part-timers shown to understand more imbalances. Younger people and more educated also understand more imbalances between work lives. However, they also report levels and control of the program from the control program improves work-life balance, may be more important for the shutdown time programming choices.

\section{OBJECTIVE OF STUDY}

To identify the influencing factors that facilitates the role conflict in balancing work and family life among married university working women. 


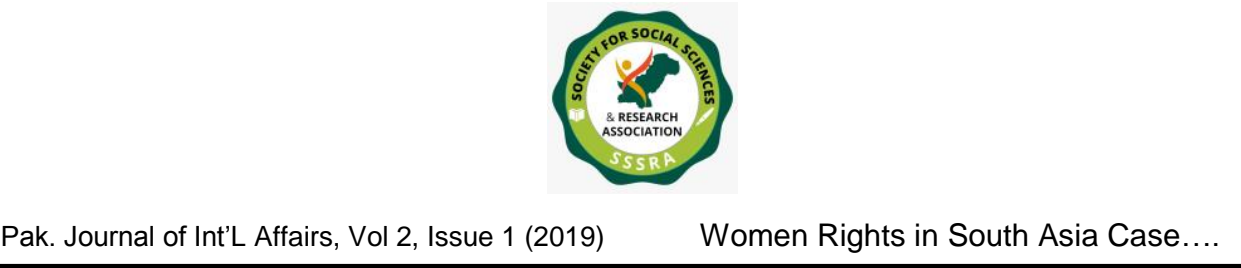

\section{HYPOTHESIS}

1. A challenge for balancing work and family of married working women is likely to be related with their time management

\section{METHODOLOGY}

Methodology systematically collects all the methods and processes used in the research study in order to solve the "problem." Some researchers even determine the methodology as a set of guidelines for the implementation of the "strategy" in a different posit The data were measured by quantitative method and based on survey research design. The study data was used to study primary and secondary sources. Secondary data were collected from various reports, bulletins, are the subject of the study, including information that is derived primarily from websites and literature, various sources to complement the survey based analysis. As primary sources of data structured questionnaires were distributed to female lecturers and professors in universities take in order to study.

\section{SELECTION OF POPULATION}

A whole group of people that are compatible with certain specifications of interest to researchers, the results can be generalized to a study described as the population ( (Polit, D. F., \&. Hungler, B. P, (1999).) Basically population of this research was working women of Higher Education at University level of Quetta city.

\section{UNIVERSAL OF THE STUDY}

This study, which was adopted in the design of survey research, was conducted in three purposively selected universities in Quetta city. The researcher choose working women from

- Sardar Bahadur Khan Women University

- Baluchistan University

- BUETEMS. 


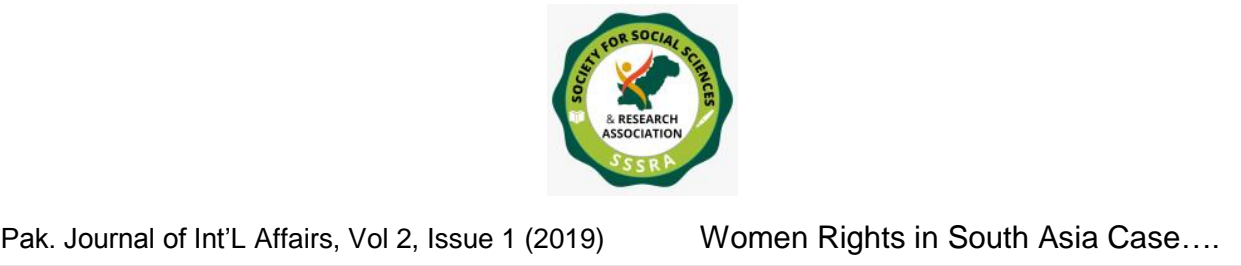

Three of these universities were semi government of Quetta city. 161 women were married from the total female faculty employees. 115 married respondents were selected as the sample who have difficulty to balance day-to-day work between family and workplace.

\section{INSTRUMENT OF DATA COLLECTION}

The questionnaire has been used as a tool to collect data for the study. Questionnaire is a quantitative research instrument to examine attitudes and behavior in humans. (Francis, 2004)). Questionnaire was the main method of data collection in order to collect demographic data a list of questions prepared in English, which bring out information about the process of socialization of the respondent Name / marital status, age, education, husband's income, jobs and level if education.

Part 2 of the questionnaire was designed to get an idea of the perception of traditional and modern role of the women by the respondent, spelling out the duties of a good housewife, the number and age of children and dependents, availability of servants, nature of household duties and their ability to managed time equally between the two domain of life.

\section{ANALYSIS OF DATA}

The collected data were coded and edited and were analyzed through using SPSS. Chi-square test was applied to analyze the factors like type of family, numbers of depends, age of children, availability of time to handle these two cores of life work and household management and its influence on the work and family life of married working women

\section{FINDINGS AND RESULT}

DEMOGRAPHIC INFORMATION OF UNIVERSITY TEACHERS

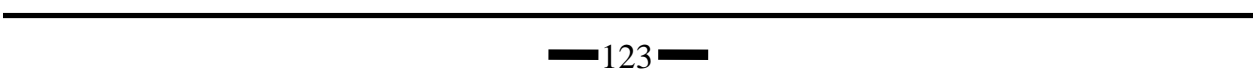




\begin{tabular}{|c|c|c|c|c|c|c|c|}
\hline \multicolumn{8}{|c|}{ respondents age } \\
\hline $\begin{array}{l}\text { Responde } \\
\text { nt's } \\
\text { duration } \\
\text { of } \\
\text { marriage }\end{array}$ & $25-29$ & $30-34$ & $35-39$ & $40-44$ & $\begin{array}{l}\mathrm{P}- \\
\text { value }\end{array}$ & $\mathrm{df}$ & $\begin{array}{l}\text { Chi- } \\
\text { square }\end{array}$ \\
\hline $1-5$ & $\begin{array}{l}49(49.2 \% \\
)\end{array}$ & $\begin{array}{l}17(54.8 \\
\%)\end{array}$ & $\begin{array}{l}0(80.0 \\
\%)\end{array}$ & $0(0.0 \%)$ & \multirow[t]{3}{*}{.000} & \multirow[t]{3}{*}{6} & \multirow{3}{*}{$\begin{array}{l}131.7 \\
97\end{array}$} \\
\hline $6-10$ & $2(3.8 \%)$ & $\begin{array}{l}13(41.9 \\
\%)\end{array}$ & $\begin{array}{l}16(80.0 \\
\%)\end{array}$ & $0(0.0 \%)$ & & & \\
\hline $11-15$ & $1(1.9 \%)$ & $1(3.2 \%)$ & $\begin{array}{l}4(20.0 \\
\%)\end{array}$ & $\begin{array}{l}12(100.0 \\
\%)\end{array}$ & & & \\
\hline \multicolumn{8}{|c|}{ respondent's qualification } \\
\hline $\begin{array}{l}\text { Responde } \\
\text { nt's } \\
\text { duration } \\
\text { of } \\
\text { marriage }\end{array}$ & M.A & M.Phil & PHD & P-value & Df & \multirow{4}{*}{\multicolumn{2}{|c|}{$\begin{array}{l}\text { Chi-square } \\
11.120\end{array}$}} \\
\hline $1-5$ & $\begin{array}{l}34(53.1 \% \\
)\end{array}$ & $\begin{array}{l}31(70.5 \\
\%)\end{array}$ & $\begin{array}{l}1(14.4 \\
\%)\end{array}$ & \multirow[t]{3}{*}{.215} & \multirow[t]{3}{*}{4} & & \\
\hline $6-10$ & $\begin{array}{l}18(28.1 \% \\
)\end{array}$ & $\begin{array}{l}8(18.2 \\
\%)\end{array}$ & $\begin{array}{l}5(71.4 \\
\%)\end{array}$ & & & & \\
\hline $11-15$ & $\begin{array}{l}12(18.8 \% \\
)\end{array}$ & $\begin{array}{l}5(11.4 \\
\%)\end{array}$ & $\begin{array}{l}1(14.3 \\
\%)\end{array}$ & & & & \\
\hline \multicolumn{8}{|c|}{ respondent's job experience } \\
\hline $\begin{array}{l}\text { Responde } \\
\text { nt's } \\
\text { duration } \\
\text { of } \\
\text { marriage }\end{array}$ & $1-4$ & $5-9$ & $10-14$ & p-value & Df & $\begin{array}{l}\text { Chi- } \\
\text { squar } \\
\mathrm{e}\end{array}$ & \\
\hline $1-5$ & $\begin{array}{l}39(95.1 \% \\
)\end{array}$ & $\begin{array}{l}27(57.4 \\
\%)\end{array}$ & $0(0.0 \%)$ & \multirow[t]{3}{*}{.000} & \multirow[t]{3}{*}{4} & \multirow{3}{*}{$\begin{array}{l}78.38 \\
3\end{array}$} & \\
\hline $6-10$ & $0(0.0 \%)$ & $8(17.0)$ & $\begin{array}{l}23(85.2 \\
\%)\end{array}$ & & & & \\
\hline $11-15$ & $2(4.9 \%)$ & $\begin{array}{l}12(25.5 \\
\%)\end{array}$ & $\begin{array}{l}4(14.8 \\
\%) \\
\end{array}$ & & & & \\
\hline \multicolumn{8}{|c|}{ respondent's husband qualification } \\
\hline $\begin{array}{l}\text { Responde } \\
\text { nt's } \\
\text { duration } \\
\text { of } \\
\text { marriage }\end{array}$ & B.A & M.A & M.phil & p-value & $\overline{\text { Df }}$ & $\begin{array}{l}\text { Chi- } \\
\text { squar } \\
\mathrm{e}\end{array}$ & \\
\hline $1-5$ & $23(62.2 \%$ & $33(53.2$ & $10(52.5$ & & & & \\
\hline
\end{tabular}




\begin{tabular}{|c|c|c|c|c|c|c|}
\hline & ) & \%) & $\%)$ & \multirow[t]{3}{*}{.007} & \multirow[t]{3}{*}{4} & \multirow{3}{*}{$\begin{array}{l}14.00 \\
5\end{array}$} \\
\hline $6-10$ & $\begin{array}{l}14(37.8 \% \\
{ }^{1}\end{array}$ & $\begin{array}{l}16(25.8 \\
\%)\end{array}$ & $1(6.3 \%)$ & & & \\
\hline $11-15$ & $0(0.0 \%)$ & $\begin{array}{l}13(21.0 \\
\%)\end{array}$ & $\begin{array}{l}5(31.3 \\
\%)\end{array}$ & & & \\
\hline \multicolumn{7}{|c|}{ respondent's husband occupation } \\
\hline $\begin{array}{l}\text { Responde } \\
\text { nt's } \\
\text { duration } \\
\text { of } \\
\text { marriage }\end{array}$ & $\begin{array}{l}\text { Governm } \\
\text { ent }\end{array}$ & private & $\begin{array}{l}\text { Busines } \\
\mathrm{s}\end{array}$ & p-value & Df & $\begin{array}{l}\text { Chi- } \\
\text { squar } \\
\mathrm{e}\end{array}$ \\
\hline $1-5$ & $\begin{array}{l}54(64.3 \% \\
)\end{array}$ & $\begin{array}{l}7(43.8 \\
\%)\end{array}$ & $\begin{array}{l}5(33.3 \\
\%) \\
\end{array}$ & \multirow[t]{3}{*}{.033} & \multirow[t]{3}{*}{4} & \multirow{3}{*}{$\begin{array}{l}10.49 \\
3\end{array}$} \\
\hline $6-10$ & $\begin{array}{l}22(26.2 \% \\
)\end{array}$ & $\begin{array}{l}4(25.0 \\
\%)\end{array}$ & $\begin{array}{l}5(33.3 \\
\%)\end{array}$ & & & \\
\hline $11-15$ & $8(9.5 \%)$ & $\begin{array}{l}5(31.3 \\
\%)\end{array}$ & $\begin{array}{l}5(33.3 \\
\%)\end{array}$ & & & \\
\hline \multicolumn{7}{|c|}{ respondent's husband qualification } \\
\hline $\begin{array}{l}\text { Responde } \\
\text { nt's } \\
\text { duration } \\
\text { of } \\
\text { marriage }\end{array}$ & B.A & M.A & M.phil & p-value & Df & $\begin{array}{l}\text { Chi- } \\
\text { squar } \\
\text { e }\end{array}$ \\
\hline $1-5$ & $\begin{array}{l}23(62.2 \% \\
)\end{array}$ & $\begin{array}{l}33(53.2 \\
\%)\end{array}$ & $\begin{array}{l}10(62.5 \\
\%)\end{array}$ & \multirow[t]{3}{*}{.007 } & \multirow[t]{3}{*}{4} & \multirow{3}{*}{$\begin{array}{l}14.00 \\
5\end{array}$} \\
\hline 6-10 & $\begin{array}{l}14(37.8 \% \\
)\end{array}$ & $\begin{array}{l}16(25.8 \\
\%)\end{array}$ & $1(6.3 \%)$ & & & \\
\hline $11-15$ & $0(0.01 \%)$ & $\begin{array}{l}13(21.0 \\
\%)\end{array}$ & $\begin{array}{l}5(31.3 \\
\%)\end{array}$ & & & \\
\hline \multicolumn{7}{|c|}{ respondent's family type } \\
\hline $\begin{array}{l}\text { Responde } \\
\text { nt's } \\
\text { duration } \\
\text { of } \\
\text { marriage }\end{array}$ & $\begin{array}{l}\text { Joint } \\
\text { family }\end{array}$ & $\begin{array}{l}\text { Neclear } \\
\text { family }\end{array}$ & p-value & Df & $\begin{array}{l}\text { Chi- } \\
\text { squar } \\
\mathrm{e}\end{array}$ & \\
\hline $1-5$ & $\begin{array}{l}57(83.8 \% \\
)\end{array}$ & $\begin{array}{l}9(19.1 \\
\%)\end{array}$ & \multirow[t]{3}{*}{.000} & \multirow[t]{3}{*}{2} & \multirow{3}{*}{$\begin{array}{l}49.05 \\
0\end{array}$} & \\
\hline $6-10$ & $9(13.2 \%)$ & $\begin{array}{l}22(46.8 \\
\%)\end{array}$ & & & & \\
\hline $11-15$ & $2(2.9 \%)$ & $\begin{array}{l}16(34.0 \\
\%)\end{array}$ & & & & \\
\hline \multicolumn{7}{|c|}{ respondent's number of children } \\
\hline Responde & $0-3$ & $4-6$ & p-value & $\mathrm{Df}$ & Chi- & \\
\hline
\end{tabular}




\begin{tabular}{|c|c|c|c|c|c|}
\hline $\begin{array}{l}\text { nt's } \\
\text { duration } \\
\text { of } \\
\text { marriage }\end{array}$ & & & & & $\begin{array}{l}\text { squar } \\
\mathrm{e}\end{array}$ \\
\hline $1-5$ & $\begin{array}{l}63(60.0 \% \\
\text { ) }\end{array}$ & $\begin{array}{l}3(30.0 \\
\%)\end{array}$ & \multirow[t]{3}{*}{.007. } & \multirow[t]{3}{*}{2} & \multirow[t]{3}{*}{9.884} \\
\hline $6-10$ & $\begin{array}{l}29(27.6 \% \\
)\end{array}$ & $\begin{array}{l}2(20.0 \\
\%)\end{array}$ & & & \\
\hline $11-15$ & $13(12.4 \%$ & $\begin{array}{l}5(50.0 \\
\%)\end{array}$ & & & \\
\hline
\end{tabular}

Demographic information helps to understand the socio-economic conditions of university teachers. The result shows that more than half of the respondents in younger age-group 25-29. $70 \%$ of the respondents have completed their M.PHIL rest of them were engage in PH.D .majority of the respondents were in initial stages of their career. $83 \%$ of the respondents belong to the joint family structure because they were in starting period of their marital life and remaining are from nuclear family. Half of the teachers have 3 to 4 kids and elderly family members at home. $52 \%$ of respondent's husbands have completed their M.PHIL. More than half of respondents husband attached with government services and remaining were engaged in business and private work. The findings further shows that more than half of the teachers have 1 to 3 children at home now a days the number of children is decided according to their economic conditions of the family. More than half of the respondents were in initial stage of their marital life.

\section{HYPOTHESIS NO 2}

A challenge for balancing work and family of married working women is likely to be related with their time management.

\begin{tabular}{|c|c|c|c|c|c|c|c|}
\hline \multicolumn{8}{|c|}{ Finding time for hobbies and leisure activities is difficult. } \\
\hline $\begin{array}{l}\text { Respondent } \\
\text { 's duration } \\
\text { of marriage }\end{array}$ & Agree & $\begin{array}{l}\text { Sometime } \\
\mathrm{s}\end{array}$ & Undecided & Disagree & $\begin{array}{l}\text { P- } \\
\text { valu } \\
\text { e }\end{array}$ & df & $\begin{array}{l}\text { Chi- } \\
\text { square }\end{array}$ \\
\hline $1-5$ & $\begin{array}{l}36(67.9 \\
\%)\end{array}$ & $\begin{array}{l}17(70.3 \\
\%)\end{array}$ & $1(33.3 \%)$ & $\begin{array}{l}11(32.4 \\
\%)\end{array}$ & .021 & 6 & 14.940 \\
\hline
\end{tabular}




\begin{tabular}{|c|c|c|c|c|c|c|c|}
\hline $6-10$ & $\begin{array}{l}12(22.6 \\
\%)\end{array}$ & $5(20.8 \%)$ & $1(33.3 \%)$ & $\begin{array}{l}13(38.2 \\
\%)\end{array}$ & & & \\
\hline $11-15$ & $5(9.4 \%)$ & $2(8.3 \%)$ & $1(33.3 \%)$ & $\begin{array}{l}10(29.4 \\
\%)\end{array}$ & & & \\
\hline \multicolumn{8}{|c|}{ I can easily manage social contact with my relatives } \\
\hline $\begin{array}{l}\text { Respondent } \\
\text { 's duration } \\
\text { of marriage }\end{array}$ & Agree & $\begin{array}{l}\text { Sometime } \\
\mathrm{s}\end{array}$ & Undecided & Disagree & $\begin{array}{l}\mathrm{P}- \\
\text { valu } \\
\mathrm{e}\end{array}$ & df & $\begin{array}{l}\text { Chi- } \\
\text { square }\end{array}$ \\
\hline $1-5$ & $\begin{array}{l}14(41.2 \\
\%)\end{array}$ & $\begin{array}{l}22(88.0 \\
\%)\end{array}$ & $1(33.3 \%)$ & $\begin{array}{l}29(54.7 \\
\%)\end{array}$ & \multirow[t]{3}{*}{.000} & \multirow[t]{3}{*}{6} & \multirow[t]{3}{*}{25.191} \\
\hline $6-10$ & $8(23.5 \%)$ & $2(8.0 \%)$ & $1(33.3 \%)$ & $\begin{array}{l}20(37.7 \\
\%)\end{array}$ & & & \\
\hline $11-15$ & $\begin{array}{l}12(35.5 \\
\%)\end{array}$ & $1(4.0 \%)$ & $1(33.3 \%)$ & $4(7.5 \%)$ & & & \\
\hline \multicolumn{8}{|c|}{ I cannot pay full attention to my family in holidays. } \\
\hline $\begin{array}{l}\text { Respondent } \\
\text { 's duration } \\
\text { of marriage }\end{array}$ & Agree & $\begin{array}{l}\text { Sometime } \\
\mathrm{s}\end{array}$ & Undecided & Disagree & $\begin{array}{l}\mathrm{P}- \\
\text { valu } \\
\mathrm{e}\end{array}$ & df & $\begin{array}{l}\text { Chi- } \\
\text { square }\end{array}$ \\
\hline $1-5$ & $\begin{array}{l}55(67.9 \\
\%)\end{array}$ & $6(60.0 \%)$ & $1(33.3 \%)$ & $4(19.0 \%)$ & \multirow[t]{3}{*}{.000} & \multirow[t]{3}{*}{6} & \multirow[t]{3}{*}{33.240} \\
\hline $6-10$ & $\begin{array}{l}12(14.8 \\
\%)\end{array}$ & $2(20.0 \%)$ & $1(33.3 \%)$ & $\begin{array}{l}16(76.2 \\
\%)\end{array}$ & & & \\
\hline $11-15$ & $\begin{array}{l}14(17.3 \\
\%)\end{array}$ & $2(20.2 \%)$ & $1(33.3 \%)$ & $1(4.8 \%)$ & & & \\
\hline \multicolumn{8}{|c|}{ I am able to spend quality time with each of my child } \\
\hline $\begin{array}{l}\text { Respondent } \\
\text { 's duration } \\
\text { of marriage }\end{array}$ & Agree & $\begin{array}{l}\text { Sometime } \\
\mathrm{s}\end{array}$ & Undecided & Disagree & $\begin{array}{l}\mathrm{P}- \\
\text { valu } \\
\mathrm{e}\end{array}$ & df & $\begin{array}{l}\text { Chi- } \\
\text { square }\end{array}$ \\
\hline $1-5$ & $\begin{array}{l}26(61.9 \\
\%)\end{array}$ & $8(50.0 \%)$ & $3(50.0 \%)$ & $\begin{array}{l}29(56.9 \\
\%)\end{array}$ & \multirow[t]{3}{*}{.000} & \multirow[t]{3}{*}{6} & \multirow[t]{3}{*}{27.214} \\
\hline $6-10$ & $2(4.8 \%)$ & $6(37.5 \%)$ & $2(33.3 \%)$ & $\begin{array}{l}21(41.2 \\
\%)\end{array}$ & & & \\
\hline $11-15$ & $\begin{array}{l}14(33.3 \\
\%)\end{array}$ & $2(12.5 \%)$ & $1(16.7 \%)$ & $1(2.0 \%)$ & & & \\
\hline \multicolumn{8}{|c|}{ when my job does not allow me to meet my family responsibilities I feel guilt } \\
\hline $\begin{array}{l}\text { Respondent } \\
\text { 's duration } \\
\text { of marriage }\end{array}$ & Agree & $\begin{array}{l}\text { Sometime } \\
\mathrm{s}\end{array}$ & Undecided & Disagree & $\begin{array}{l}\text { P- } \\
\text { valu } \\
\mathrm{e}\end{array}$ & $\begin{array}{l}\text { D } \\
\mathrm{f}\end{array}$ & $\begin{array}{l}\text { Chi- } \\
\text { square }\end{array}$ \\
\hline $1-5$ & $\begin{array}{l}24(42.1 \\
\%)\end{array}$ & $7(63.6 \%)$ & $\begin{array}{l}10(83.3 \\
\%)\end{array}$ & $\begin{array}{l}25(71.4 \\
\%)\end{array}$ & \multirow[t]{3}{*}{.022} & \multirow[t]{3}{*}{6} & \multirow{3}{*}{$\begin{array}{l}14.765 \\
4\end{array}$} \\
\hline $6-10$ & $\begin{array}{l}21(36.8 \\
\%)\end{array}$ & $1(9.1 \%)$ & $1(8.3 \%)$ & $8(22.9 \%)$ & & & \\
\hline $11-15$ & $12(211$ & $3(273 \%)$ & $1(83 \%)$ & $2(57 \%)$ & & & \\
\hline
\end{tabular}




\begin{tabular}{|c|c|c|c|c|c|c|c|}
\hline & $\%)$ & & & & & & \\
\hline \multicolumn{8}{|c|}{ I worried about the effect of work stress on my health. } \\
\hline $\begin{array}{l}\text { Respondent } \\
\text { 's duration } \\
\text { of marriage }\end{array}$ & Agree & $\begin{array}{l}\text { Sometime } \\
\mathrm{s}\end{array}$ & Undecided & Disagree & $\begin{array}{l}\text { P- } \\
\text { valu } \\
\text { e }\end{array}$ & $\begin{array}{l}\text { D } \\
\text { f }\end{array}$ & $\begin{array}{l}\text { Chi- } \\
\text { square }\end{array}$ \\
\hline $1-5$ & $\begin{array}{l}29(40.8 \\
\%)\end{array}$ & $\begin{array}{l}26(89.7 \\
\%)\end{array}$ & $1(33.3 \%)$ & $\begin{array}{l}10(83.3 \\
\%)\end{array}$ & \multirow[t]{3}{*}{.000} & \multirow[t]{3}{*}{6} & \multirow[t]{3}{*}{24.632} \\
\hline $6-10$ & $\begin{array}{l}27(38.0 \\
\%)\end{array}$ & $2(6.9 \%)$ & $1(33.3 \%)$ & $1(8.3 \%)$ & & & \\
\hline $11-15$ & $\begin{array}{l}15(21.4 \\
\%)\end{array}$ & $1(3.4 \%)$ & $1(33.3 \%)$ & $1(8.3 \%)$ & & & \\
\hline
\end{tabular}

$67 \%$ of the respondents whose marital experience lies in category of 1-5 face more difficulty in finding time for their hobbies or personal interest $(\mathrm{p}=0.021)$ which effect their mental and physical health, in the same class $54 \%$ of women are unable to maintain social contacts with their social circle due to the high pressure of dual role responsibilities (chisquare $=25.191 ; \mathrm{df}=6 ;<\mathrm{p}=0.000) 24 \%$ of the respondents feel guilt when they cannot manage their time between their work and family life. On the other hand respondents of marital experience with 6 to 15 years are able to cope with this time conflict in balancing their double lives at home and office. It indicates that years of marital life is significantly associated with time management in women's dual roles.

The findings illustrate those women with initial years of their marital life find difficulties in time management between their dual lives because at that stage they have the responsibility of small kids with domestic core management as well as they required extra potential and abilities to cope with office demands which creates role conflict for them and that ultimately affect their work life balance and health as well in contrast to those who have passed that stage of marital life.

\section{DISCUSSION}

Women, especially Pakistani women, compensate more concentration to the family than their profession. The findings of this study confirm that those women who have 8 to 10 years duration of their marriage easily handle family and work life than those who were newly entered in their 


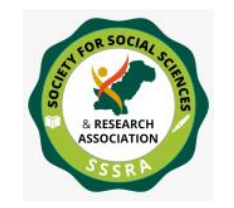

Pak. Journal of Int'L Affairs, Vol 2, Issue 1 (2019)

Women Rights in South Asia Case....

dual role than women with young children. In the same way, working women who have to take care of older parents / in-laws health tasks reported more imbalances in two domains than their co-workers. . The requirement for child care while away from home is a very important aspect that disturbs your mind and diverts your interest from your administrative center. The existence of an employee in relaxed surroundings within the organization will support employees and motivates them to complete the assignment assigned at a specific time. The ability to accomplish this task at the same time is a strong factor to achieve a balance between work and life. (Perlow.L.A, 1995) . (Netemeyer, (1996) ) Described the conflict between work and family as "a form of conflict between roles in which public demands, time spent and work pressure overlap in the performance of family responsibilities." (Greenhaus \& Beutell, 1985); subsequently, higher work requests may constrain or anticipate people from investing quality time with their families, which can lead to lower fulfillment with family life. More workers may have to see after their elderly relatives, which will increment their obligation of care for dependent seniors, and lead to higher levels of work-family friction. (Frone, (1992) ) (Greenhaus, (1985))

To 'choose whether there are distinctive impacts of positive adjust and negative adjust on quality of life, it is fundamental to recognize people who display a elevated enrich up to level of engagement over their combined work and family measures from those who show a moo add up to level of engagement. For illustration, those people who commit a considerable quantity of time to their combined work and family shares and disperse this considerable time similarly between the two parts display positive time adjust. By differentiate, those people who give as it were a restricted sum of time to their combined work and family parts and disseminate the constrained time similarly between the two parts show negative time adjust. Adjusted fulfillment over work and family parts (Clark, (2000).) (Kirchmeyer, (2000)) 2; (Kofodimos, (1993) it is possible to connect with a high quality life. Those people who are satisfied with both the characters are more likely to experience more important successes than those who are satisfied with any other role, and the success of the goal is exceptional. (Diener, (1999) 


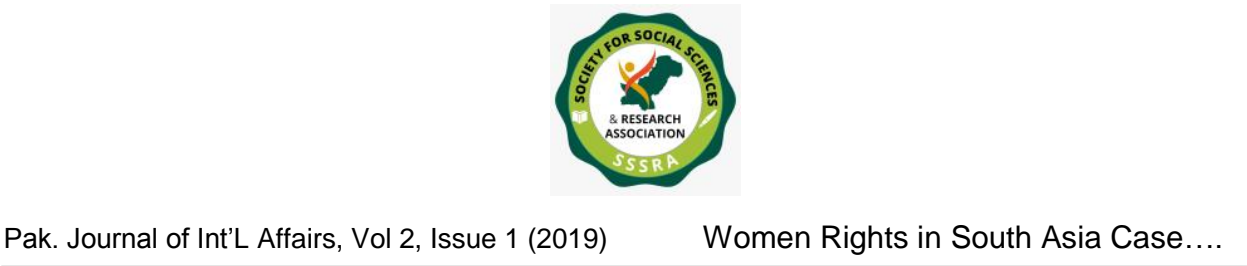

\section{CONCLUSION}

The participation of women in economic life is important for the progress of the country and improving the quality of life for families. Employed women face a double role in the world. This double role leads to work family conflict. There are few expectations from woman, both in the family and in the professional side. These expectations require two different women in one woman. To successfully implement roles, she has to work with a strict routine with more physical and mental capability to deal with critical situations timely. But, because of the extra responsibilities women suffer from work life imbalance and work-life conflict that in the end affect their pleasure with life. By identifying these key factors the study may provide better in-sights to family members, human resources professionals and consultants to manage to launch efforts to improve the life satisfaction of working women. Despite the problems they face, most were completely satisfied with their jobs, and most of them are contributing to pay their household everyday expenditure

\section{RECOMMENDATION}

Following recommendations are being proposed which may be considered to empower the working women

This study found little relaxation in the office hours making life much more relaxed of working women especially mothers. Working mothers also feel difficulty leaving their small children at home. That's why the need is felt that organizations should provide facilities in the form of flexible time.

Organizations should facilitate working mothers with child care center with in jobs location with qualified personnel.

Moreover, organizations must provide working mothers with transport facilities and job opportunities shared. If the member of staff is frustrated he / she will unable to contribute positively in improvement and production of organizations. 


\section{LIMITATION AND SCOPE FOR THE FURTHER IMPLICATIONS:}

1. The study was conducted in a narrow range relatively where the sample size with the 115 respondents from three semigovernmental universities of Quetta, and it could in the future be searched with increasing sample size in various other sectors of Pakistan to promote and develop the understanding of the relationship of conflict between work and family and balance between work and life among Pakistani workers.

2. Future research may want to look into different relationships of WFB and job/ personal satisfaction with respect to working female that are single with no children.

3. The study was based on respondent's ability to manage their time within work and family life; further studies can be done on availability of supportive environment in these two domains, job satisfaction, attitude of husband and marital relations etc.

4. The study was limited only to working women it can be further extended to working women and men both. 


\section{REFERENCES}

Begum, A. D. (2002). Measuring socio-economic. In A. D. Begum, Measuring socio-economic gender inequality in: Towards an alternative to the UNDP gender-related development index. The Hague: Instt. of Social Studies.

Clark, S. C. ( (2000). Work/family border theory: A new theory of work/family balance. Human Relations,53(6), 747-770.

Souza, C. D. (1963). The call of working Mother. Social Action, 640-646.

Desai, V. (1967). Social Aspects of Savings, Bombay: Popular Prakashan.

Diener, E. S. ((1999). Subjective well-being: Three decades of progress. . Psychological Bulletin, , 125(2), 276-302.

Francis, J. J. (2004). Constructing Questionnaires Based On The Theory Of Planned Behaviour A Manual For Health Services Researchers. UK: University Of Newcastle.

Frone, M. R. ((1992) ). Antecedents and outcomes of work-family conflict: Testing a model of work-family interface, Journal of Applied Psychology, 77 (1), 65-78.

Greenhaus, J. H. ( (1985). Sources of conflict between work and family roles. Academy of Management Review, 10 (1), 76-88.

Guest, D. (2002). Perspectives on the study of work-life balance. Social ScienceInformation, 41(2), 255-79.

Hochschild, A. (1997). The Time Bind: When Work Becomes Home and Home Becomes Work. New York, NY: Metropolitan Books.

Hom, P.W. \& Kinicki, A.J. (2001). Toward a greater understanding of how dissatisfaction drives, employee turnover. The Academy of Management Journal, 44(5), 975- 987.

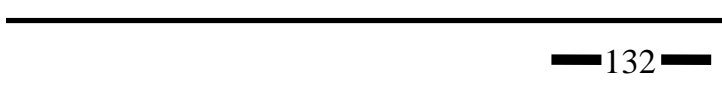


Kofodimos, J. R. (1993). Balancing act. San Francisco: Jossey-Bass.

Tausig M and Fenwic, R. (2001). Unbinding Time: Alternate Work Schedules Work-Life Balance. Journal of Family and Economic Issues, 22(2), 101-119.

Neetu, 1. (2009). Social Justice \& Empowerment. Retrieved from https://www.google.com/search?rlz=1C1CHBF_enPK831PK831\& $\mathrm{q}=\mathrm{Neetu},+1 .+((2009)) .+$ Social+Justice+\%26+Empowerment.\&tbm $=$ isch $\&$ source $=$ univ\&sa $=$ X\&ved $=2$ ahUKEwi-o_njcfgAhUKyoUKHTrLC_IQ7Al6BAgDEA0\&biw=1366\&bih= 657

Netemeyer, R. B. ( (1996) ). Development and validation of work - family conflict and family - work conflict scales. Journal of Applied Psychology, 81(4), 400-410.

Nye, F.I.Hoffman, L.W. (1963). The Employed Women in America. Chigago: Rand Mcmally and Company.

Perlow.L.A. (1995). Putting the work back into work/family. Group and Organization Management, 20(2), 227-39.

Sinha, P. (1976). Role conflict among Working Women. New Delhi: Janaki Prakashan. 